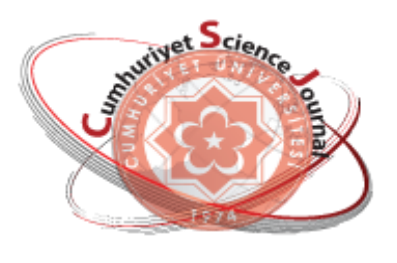

e-ISSN: $2587-246 X$

ISSN: $2587-2680$

\section{Cumburiyet Scionce Journal esy}

Cumhuriyet Sci. J., Vol.39-3(2018) 688-693

\title{
Immobilization of Laccase in poly (Vinyl Alcohol)-Calcium Alginate Beads
}

\author{
Haydar ALTINOK \\ Kırlkkale University, Faculty of Arts and Sciences, Department of Chemistry, Kirikkale, TURKEY \\ Received: 26.04.2018; Accepted: 12.09.2018 \\ http://dx.doi.org/10.17776/csj.418897
}

\begin{abstract}
Laccase enzyme (L) obtained from Tramates versicolor was entrapped into polyvinyl alcoholcalcium alginate (PVA-CaAlj) beads. Michaelis-Menten constant $(\mathrm{Km})$ and maximum reaction rate (Vmax) values were found to be $1.70 \times 10^{-2} \mathrm{mM}$ and $2.08 \times 10^{-3} \mathrm{mM} \cdot \mathrm{min}^{-1}$ for free enzyme respectively. $\mathrm{Km}$ and Vmax values were found as $2.87 \times 10^{-2} \mathrm{mM}$ and $5.30 \times 10^{-3} \mathrm{mM}^{-\mathrm{min}^{-1}}$ for entrapped enzymes respectively. Optimum $\mathrm{pH}$ was determined as 5.0 and 6.0 and optimum temperature determined as $40^{\circ} \mathrm{C}$ and $45^{\circ} \mathrm{C}$ for free laccase and entrapped laccase respectively. After 30 days of storage at $4{ }^{\circ} \mathrm{C}$ free laccase retained $60 \%$ of its original activity. Also after 30 days of storage at $4{ }^{\circ} \mathrm{C}$, entrapped enzymes were retained $85 \%$ its original activity. Immobilized enzyme was used repeatedly 10 times, were retained $75 \%$ of its original activities.
\end{abstract}

Keywords: Laccase, immobilization, polyvinyl alcohol-calcium alginate, entrapment.

\section{Lakkazın poli (Vinil Alkol) -Kalsiyum Aljinat Kürelerine İmmobilizasyonu}

\begin{abstract}
Özet. Tramates versicolor' dan elde edilen lakkaz enzimi (L), polivinil alkol-kalsiyum aljinat (PVA-CaAlj) kürelerine hapsedildi. Michaelis-Menten sabiti $(\mathrm{Km})$ ve maksimum reaksiyon hızı (Vmax) değerleri sırasıyla

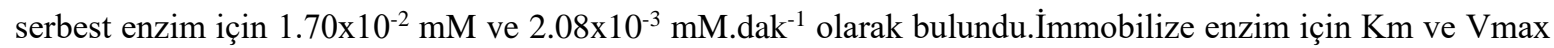

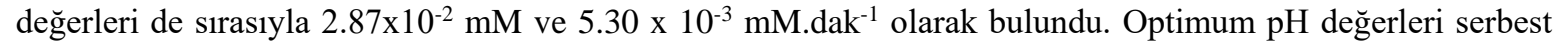
enzim için 5.0 ve immobilize enzim için 6.0 olarak belirlendi. Optimum sıcaklık sırasıyla serbest lakkaz ve immobilize lakkaz için $40^{\circ} \mathrm{C}$ ve $45^{\circ} \mathrm{C}$ olarak belirlendi. $4{ }^{\circ} \mathrm{C}$ tutulan serbest lakkazın 30 günlük depolama sonrasında orijinal aktivitesinin \% 60' orijinal aktivitesinin\% 85'ini koruduğu bulundu. İmmobilize enzimin $10 \mathrm{kez}$ tekrar kullanım sonrasında orijinal aktivitesinin \% 75'ini koruduğu bulunmuştur.
\end{abstract}

Anahtar Kelimeler: Lakkaz, immobilizasyon, polyvinil alkol-kalsiyum aljinat, tutuklama.

\section{INTRODUCTION}

Enzyme catalysed reactions are very important in biotechnology. Immobilizations of enzymes are useful techniques that provide continuous and repeated use in enzymatic processes and applications. [1-3]. Laccase (benzenediol: oxygen oxidoreductase, EC 1.10.3.2), a type of multicopper oxidase which is a biocatalyst. Laccase can able to catalyse reduction of oxygen to water [4-6]. Fungi, plants and some bacteria are laccase production resources [7-10].
Several supports have been used for immobilization of laccase by entrapment method, such as entrapment in polymeric gels [11], entrapment on polyacrylamide semiinterpenetrating polymer networks [12], entrapment on Semi-interpenetrating polymer networks [13], entrapment on Polyacrylamidebased semi-interpenetrating networks [14], entrapment into carrageenan based semiinterpenetrating polymer Networks [15] . 
In this study laccase was immobilized polyvinyl alcohol-calcium alginate (PVA-CaAlj) beads by entrapment. Effects of immobilization on enzyme activity, kinetic parameters, storage stability and reuse capability of the laccase were investigated.

\section{MATERIALS AND METHODS}

\section{Materials}

Laccase (EC 1.10.3.2.) from Trametes versicolor were supplied from Fluka. Sodium alginate and syringaldazine were supplied from Sigma. Polyvinyl alcohol, Calcium chloride $\mathrm{CaCl}_{2}$, Citric acid and sodium hydroxide were supplied from Merck. Ammonium persulphate (APS) was supplied from Analar. Phosphoric acid and Ethyl alcohol were supplied from Riedel-de Haen. All chemicals used were analytical grade in this study.

Immobilization of laccase into polyvinyl alcohol-calcium alginate (PVA-CaAlj) beads

Laccase was immobilized into (poly (vinyl alcohol)-Ca alginate) beads by entrapped method. $50 \mathrm{~mL}, 1 \% \mathrm{w} / \mathrm{w}$ Sodium alginate dissolved in distilled water and $50 \mathrm{~mL}, 2 \% \mathrm{w} / \mathrm{w}$ poly (vinyl alcohol) dissolved in distilled water were thoroughly mixed. Then Laccase enzyme was dissolved in phosphate buffer ( $\mathrm{pH}: 6.5,0.04 \mathrm{M}$ ) were added to the solution and mixed well. Fallowing this resulting homogenous mixtures were added drop wise from a burette to the $0.3 \mathrm{M}$ $\mathrm{CaCl}_{2}$ solution. When Na-alginate was contacted with $\mathrm{CaCl}_{2}$, enzyme molecules were immobilized in water-insoluble $\mathrm{Ca}$-alginate poly (vinyl alcohol) spheres due to sodium-calcium exchange. The resulting polymeric spheres were then stored in distilled water at $4{ }^{\circ} \mathrm{C}$ for later use.

\section{Determination of laccase activity}

Determination of laccase activity for free and immobilized form was assayed spectrophometrically as defined by Leonowicz and Grzywnowicz [16].

Spectrophotometric measurements were carried out with Shimadzu UV-Visible spectrophotometer
UV/Vis. 1800 at $530 \mathrm{~nm}$ and enzyme activities were determined with the help of syringaldazine calibration curve.

\section{Effect of Temperature and pH}

Effects of Temperature and $\mathrm{pH}$ for free and immobilized laccase activities were determined under different $\mathrm{pH}$ and temperatures range.

\section{Storage Stability}

The storage stability of the free and entrapped laccase was measured in 30 days. Free and entrapped laccase were kept in Phosphate buffer at $4{ }^{\circ} \mathrm{C}$.

\section{Kinetic Studies}

Kinetic parameters of Michaelis-Menten equation $\mathrm{K}_{\mathrm{m}}$ and $\mathrm{Vmax}$ were determined for free and immobilized laccase at constant temperature and $\mathrm{pH}$ for various syringaldazine concentrations.

\section{Repeated use of Immobilized Laccases}

Immobilized laccase enzyme was used 10 times in a day. Temperature, $\mathrm{pH}$ and substrate concentration were kept constant in each reaction.

\section{RESULTS AND DISCUSSION}

\section{Effects of Temperature and $\mathrm{pH}$}

The activity of the free and immobilized laccase at different $\mathrm{pH}$ values is shown in Figure 1. Optimum $\mathrm{pH}$ was determined as 5.0 and 6.0 for free laccase and entrapped laccase respectively. Similar results have been reported for free laccase related laccase sources and substrates [12, 17-19]. For immobilized laccase optimum similar $\mathrm{pH}$ values have been reported previously [12-15, 17-19]. The $\mathrm{pH}$ value in this study was found to be relevant with previous studies. The activity of the free and immobilized laccase at different temperature values is in the Figure 2. The optimum temperature was determined as $40^{\circ} \mathrm{C}$ and $45^{\circ} \mathrm{C}$ for free laccase and entrapped laccase respectively. Optimum temperature of entrapped laccase value was found higher than optimum temperature value of free 
laccase. Similar result have been reported in previous studies [12-15].

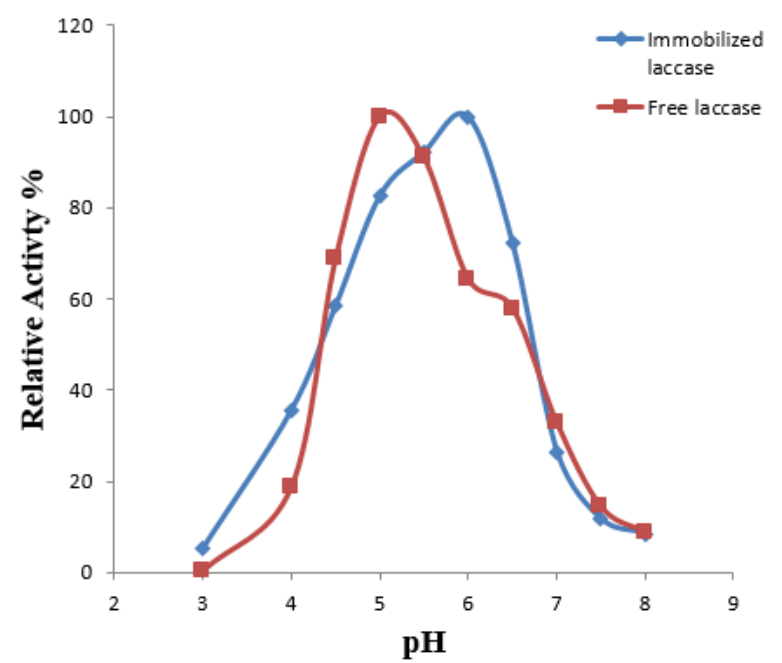

Figure 1. Effect of $\mathrm{pH}$ on the activity of free and immobilized enzyme.

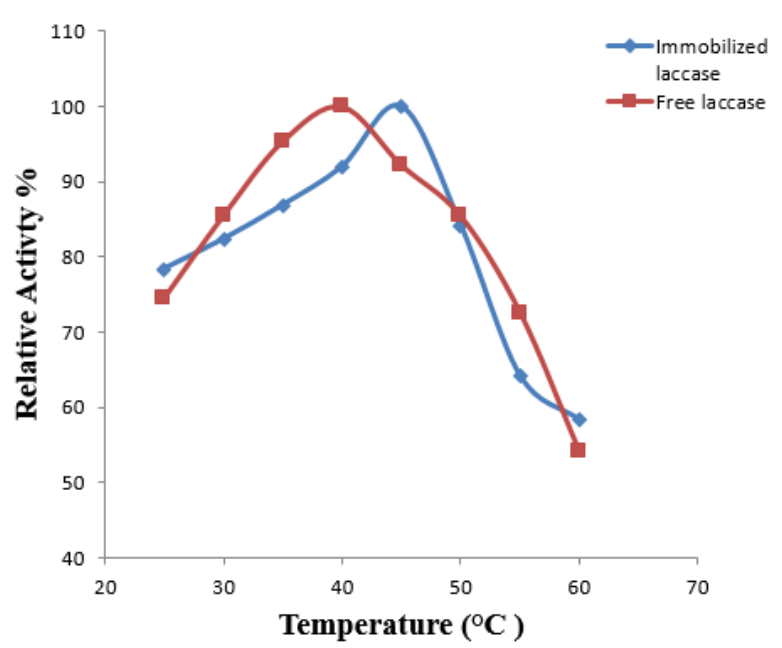

Figure 2. Effect of temperature on the activity of free and immobilized enzyme.

\section{Storage Stability}

The free and entrapped laccases were kept at $4{ }^{\circ} \mathrm{C}$ and the activities of free and entrapped enzyme were measured periodically over duration of 30 days. The entrapped laccase retained $85 \%$ of its starting activity while free laccase retained $60 \%$ of starting activity when stored in buffer solution for 30 days. The results are shown in Figure 3. In literature, glaceraldehyde crossed laccase on magnetic chitosan nanoparticles maintained $85 \%$ of activity after 30 days [20]. When laccase was immobilized with covalent attachment to DEAEGranocel 500, CM-Granocel and acrylic carrier, it was reported to retain $90 \%$ of the activity of the immobilized laccase when stored at $4{ }^{\circ} \mathrm{C}$ for 4 months [18]. When laccase was immobilized with glutaraldehyde crosslinker by adsorption on chitosan microspheres and $\mathrm{Fe}^{+3}$ transition metal chelates, the enzyme immobilized on the chelate at $4{ }^{\circ} \mathrm{C}$ for 3 months and the water-soluble chitosan [21]. That the enzyme immobilized on the microspheres preserves $90 \%$ of the activity of the enzyme immobilized thereon, whereas the enzyme immobilized on the microspheres retains $85 \%$ of the activity. Our results are consistent with the results in the literature.

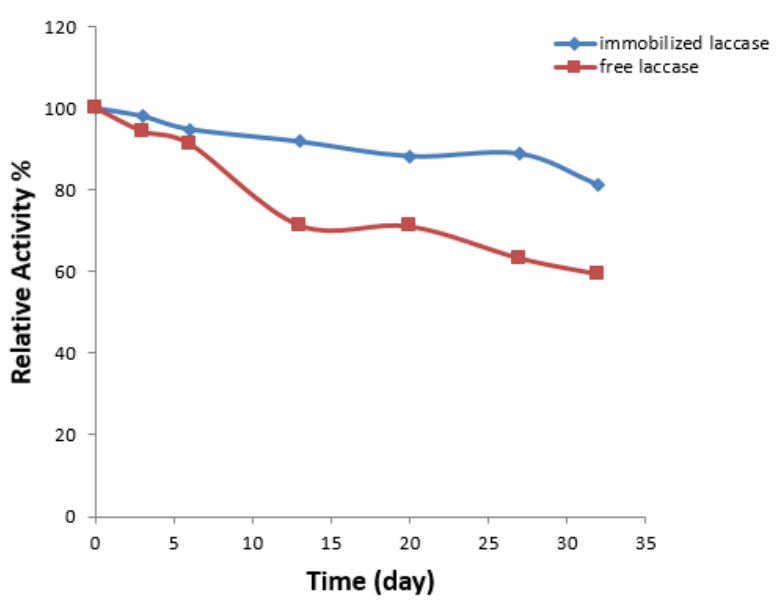

Figure 3. Effect of storage on the activity of free and immobilized enzyme.

\section{Kinetics Parameters}

The kinetic parameters results of free and immobilized laccase are presented in Table 1. Michaelis-Menten constant (Km) and maximum reaction rate $(V \max )$ values were estimated from the Lineweaver-Burk plots [22]. Km and Vmax values were found as $1.70 \times 10^{-2} \mathrm{mM}$ and $2.08 \times 10^{-3}$ $\mathrm{mM} \cdot \mathrm{min}^{-1}$, for free enzyme respectively. $\mathrm{Km}$ and Vmax values were found as $2.87 \times 10^{-2} \mathrm{mM} 5.30 \mathrm{x}$ $10^{-3} \mathrm{mM} \cdot \mathrm{min}^{-1}$, for entrapped enzymes respectively (Figure 4.). In the light of the results of the experiment, it is seen that $\mathrm{Km}$ and Vmax values are increased by immobilization of the enzyme. The value of $\mathrm{Km}$ is increased by immobilization of the 
enzyme this behaviour can be caused microenvironmental effects. In literature, When Laccase immobilized on magnetic chitosan nanoparticles $\mathrm{Km}$ value was reported to $31.1 \mu \mathrm{M}$ [20]. When Eupergite was immobilized, they found that the $\mathrm{Km}$ was $0.150 \mathrm{mM}$ and the $\mathrm{Vmax}$ value was 7.6 $\mathrm{x} 10^{-3} \mathrm{mM} \cdot \mathrm{min}^{-1}[5]$.

Table 1. Kinetic parameters of free and immobilized enzymes.

\begin{tabular}{lcc}
\hline & $\mathrm{K}_{\mathrm{m}}(\mathrm{mM})$ & $\mathrm{V}_{\max }\left(\mathrm{mM} \cdot \mathrm{min}^{-1}\right)$ \\
\hline Free enzyme & $1.70 \times 10^{-2}$ & $2.08 \times 10^{-3}$ \\
Immobilized enzyme & $2.87 \times 10^{-2}$ & $5.30 \times 10^{-3}$ \\
\hline
\end{tabular}

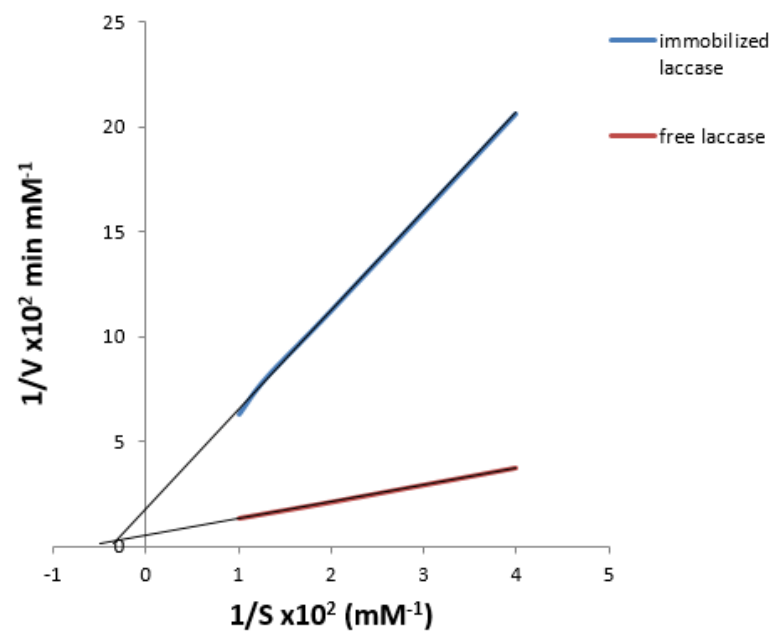

Figure 4. Lineweaver-Burk plots for free and immobilized enzyme.

\section{Repeated use of immobilized enzymes}

In this study, entrapped laccase into (poly (vinyl alcohol)-Ca alginate) beads were repeated in 10 cycles in a day. The immobilized enzymes were protected $75 \%$ of its original activities. Repeated use effect of immobilized laccase activity was presented in Figure 5.

In literature, it has been found that glaceraldehydecrosslinked laccase on magnetic chitosan nanoparticles maintains about $85 \%$ of activity after 10 times used [20]. Laccase was immobilized on the amine-terminated nanocomposites (Cu TPAc) $\mathrm{Fe}_{3} \mathrm{O}_{4}$ (copper tetraamin phthalocyanine) with gulutaraldehyde crosslinker and was found to retain $80 \%$ of activity after 5 times of use [23]. The enzyme laccase immobilized by covalent attachment on activated PVA has been found to retain $60 \%$ of its activity after 10 times used [24].

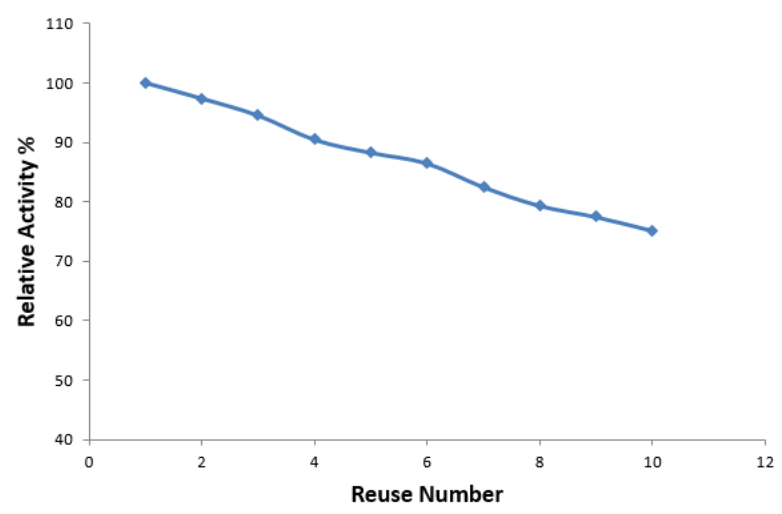

Figure 5. Effect of reuse on the activity of immobilized enzyme.

\section{CONCLUSIONS}

Laccase enzyme was immobilized by entrapment method into polyvinyl alcohol-calcium alginate (PVA-CaAlj) beads and the immobilization process was optimized.

It has been found that optimum $\mathrm{pH}$ and temperature values are better when compared to the immobilized enzyme free enzyme

Entrapped laccase into (poly (vinyl alcohol)-Ca alginate) beads was found to have better temperature, $\mathrm{pH}$ and strorage stability when compared to the free enzyme. The immobilized enzymes were protected $75 \%$ of its original activities. These properties of immobilized laccase enzyme can be used for various biotechnological and industrial applications, such as in waste water treatment.

\section{Acknowledgement}

This research was supported by the Kirikkale University. Research Grant, BAP (Project number: 2011-23) 


\section{REFERENCES}

[1]. Laurent N., Haddoub R., Flitsch SL., Enzyme catalysis on solid surfaces, Trends Biotechnol., 26 (2008) 328-337.

[2]. Tischer W. and Kasche V., Immobilized enzymes: crystals or carriers, Trends Biotechnol., 17 (1999) 326-335.

[3]. Pang R., Li M., Zhang C., Degradation of phenolic compounds by laccase immobilized on carbon nanomaterials: Diffusional limitation investigation, Talanta., 131(2015) 38-45.

[4]. D'annibale A., Stazi S.R., Vinciguerra V., Mattia E.D., Sermanni G.G., Characterization of immobilized laccase from Lentinula edodes and its use in olivemill wastewater treatment, Process Biochem., 34 (1999) 697-706.

[5]. D'annibale A., Stazi S.R., Vinciguerra V., Sermanni G., Oxirane-immobilized Lentinula edodes laccase: stability and phenolics removal efficiency in olive mill wastewater, J Biotechnol., 77 (2000) 265273.

[6]. Jiang D.S., Long S.Y., Huang J., X1ao H.Y., Zhou J.Y., Immobilization of Pycnoporus sanguineus laccase on magnetic chitosan microspheres, Biochem. Eng. J., 25 (2005) 15-23.

[7]. Durán N., Rosa M.A., D'annibale A., Gianfreda L., Applications of laccases and tyrosinases (phenoloxidases) immobilized on different supports: a review, Enzyme Microb. Tec., 31(2002) 907-931.

[8]. Jolivalta C., Brenon S., Caminade E., Mougin C., Pontié M., Immobilization of laccase from Trametes versicolor on a modified PVDF microfiltration membrane: characterization of the grafted support and application in removing a phenylurea pesticide in wastewater, J. Membrane Sci., 180(2000) 103-113.

[9]. Wan Y., Lu R., Xiao L., Du Y., Miyakoshi T., Chen C., Knill C., Kennedy J., Effects of organic solvents on the activity of free and immobilised laccase from Rhus vernicifera, Int. J. Biol. Macromol., 47 (2010) 488-495.
[10]. Rotkova J., Sulakova R., Korecka L., Zdrazilova P., Jandova M., Lenfeld J., Horak D., Bilkova Z., Laccase immobilized on magnetic carriers for biotechnology applications, J. Magn. Mater., 321 (2009) 1335-1340.

[11]. Curulli A., Cusma A., Kaciulis S., Padeletti G., Pandolfi L., Valentini F., Vitocelli M., Immobilization of GOD and HRP enzyme on nanostructured substrates, Surf. Interface Anal., 38 (2006) 478-481.

[12]. Gokgoz M. and Altinok H., Immobilization of laccase on polyacrylamide and polyacrylamide $-\kappa$ - carragennan-based semi-interpenetrating polymer networks, Artificial Cells, Blood Substitutes, and Biotechnology, 40 (2012) 326-330.

[13]. Yamak O., Kalkan N.A., Aksoy S., Altinok H., Hasirci N., Semi-interpenetrating polymer networks (semi-IPNs) for entrapment of laccase and their use in Acid Orange 52 decolorization, Process Biochemistry, 44 (2009) 440-445.

[14]. Koklukaya S.Z., Sezer S., Aksoy S., Hasirci N., Polyacrylamide-based semiinterpenetrating networks for entrapment of laccase and their use in azo dye decolorization, Biotechnology and Applied Biochemistry, 63(5) (2016) 699-707.

[15]. Makas Y.G. , Kalkan N.A., Aksoy S., Altinok H., Hasirci N., Immobilization of laccase in -carrageenan based semiinterpenetrating polymer Networks, Journal of Biotechnology, 148 (2010) 216-220.

[16]. Leonowicz A. and Grzywnowicz K., Quantitative estimation of laccase forms in some white rot fungi using syringaldazine as a substrate, Enzyme Microb. Tech., 3 (1981) $55-58$.

[17]. Lante A., Crapisi A., Krastanov A., Spettoli P., Biodegradation of phenols by laccase immobilised in a membrane reactor, Process Biochem., 36 (2000) 5158.

[18]. Al-Adhami A.J.H., Bryjak J., Markiewicz B.G., Chozch W.P., Immobilization of woodrotting fungi laccases on modified 
cellulose and acrylic carriers, Process Biochem., 37 (2002)1387-1394.

[19]. Dodor D.E., Hwang H., Ekunwe S., Oxidation of anthracene and benzo[a]pyrene by immobilized laccase from Trametes versicolor, Enzyme Microb. Tech., 35 (2004) 210-217.

[20]. Fang H., Huang J., Ding L., Li M., Chen Z., Preparation of magnetic Chitosan nanoparticles and immobilization of Laccase, Journal of Wuhan University of Technology-Mater. Sci. Ed., 24 (2009) 4247.

[21]. Yang W.Y., Min D.Y., Xiao S.W., Jin L., Rong L., Tetsuo M., Bo C., Immobilization and characterization of laccase from Chinese Rhus vernicifera on modified chitosan, Process Biochem., 41 (2006) 1378-1382.

[22]. Lineweaver H. and Burk D.J., The determination of enzyme dissociation constant, Am. Chem. Soc., 56 (1934) 658 666.

[23]. Xiao H., Huang J., Liu C., Jiang D., Immobilization of Laccase on amineterminated magnetic nano-composite by glutaraldehyde crosslinking method, T. Nonferr. Metal Soc., 16 (2006) 414-418.

[24]. Zamora P. P., Pereira M. C., Tiburtius R. L., Rosa M.A., Minussi C.R., Duran N., Decolarization of reactive dyes by immobilized Laccase, Appl. Catal BEnviron ., 42 (2003) 131-144. 